\title{
Antidepressant-Like Effect of Different Estrogenic Compounds in the Forced Swimming Test
}

\author{
Erika Estrada-Camarena*, 1,2 , Alonso Fernández-Guasti' and Carolina López-Rubalcava' \\ 'Depto de Farmacobiología CINVESTAV-IPN, México DF, México; 'Instituto Nacional de Psiquiatría, Ramón de la Fuente, México DF, México
}

\begin{abstract}
The present study evaluated the possible antidepressant-like action of the natural estrogen $17 \beta$-estradiol $\left(E_{2}, 2.5-10 \mu \mathrm{g} / \mathrm{rat}\right)$, the synthetic steroidal estrogen ethinyl-estradiol ( $\left.\mathrm{EE}_{2}, 1.25-10.0 \mu \mathrm{g} / \mathrm{rat}\right)$, and the nonsteroidal synthetic estrogen, diethyl-stilbestrol (DES, 0.25-1.0 mg/ rat) in ovariectomized adult female Wistar rats using the forced swimming test (FST). The behavioral profile induced by the estrogens was compared with that induced by the antidepressants fluoxetine (FLX, 2.5-10 mg/kg) and desipramine (DMl, 2.5-10 mg/kg). In addition, the temporal course of the antidepressant-like action of the estrogenic compounds was analyzed. FLX and DMI induced an antidepressant-like effect characterized by a reduced immobility and increased swimming for FLX and decreased immobility and increased climbing for DMI. Both $E_{2}$ and $E_{2}$ produced a decrease in immobility and an increase in swimming, suggesting an antidepressant-like action. DES did not affect the responses in this animal model of depression at any dose tested. The time course analysis of the actions of $\mathrm{E}_{2}(10 \mu \mathrm{g} / \mathrm{rat})$ and $\mathrm{EE}_{2}(5 \mu \mathrm{g} / \mathrm{rat})$ showed that both compounds induced an antidepressant-like effect observed I h after their injection lasting for $2-3$ days.

Neuropsychopharmacology (2003) 28, 830-838, advance online publication, 12 March 2003; doi: I 0. I 038/sj.npp. I 300097
\end{abstract}

Keywords: $17 \beta$-estradiol; ethynil-estradiol; diethyl-stilbestrol; antidepressants; forced swimming test; fluoxetine; desipramine

\section{INTRODUCTION}

Clinical evidence suggests that the vulnerability to depression of some women is associated with the hormonal fluctuations during their life, in which estrogens play an important role (Halbreich et al, 1986; Hamilton et al, 1988; Hendrick et al, 1998; Oppenheim, 1983; Stahl 1997, 1998b). For example, chronic treatment of these women with $17 \beta$ estradiol $\left(E_{2}\right)$ or conjugated equine estrogens decreased depressive symptoms during the perimenopausal and postpartum periods (Ahonkas et al, 1999; Epperson et al, 1999; Genazzani et al, 1999; Klaiber et al, 1979; LópezJaramillo et al, 1996; Österlund and Hurd, 2001). Indeed, it has been suggested that estrogens could shorten or improve the therapeutic action of some antidepressants (Prange, 1972; Schneider et al, 1997, 2001). Furthermore, preclinical reports refer that $\mathrm{E}_{2}$ produces antidepressant-like actions in animal models of depression such as the forced swimming and the tail suspension tests (Bernardi et al, 1989; Galea et al, 2001; Okada et al, 1997; Rachman et al, 1998).

Antidepressants such as the selective serotonin reuptake inhibitors (SSRIs; ie fluoxetine (FLX), sertraline) and

\footnotetext{
* Correspondence: Dr E Estrada-Camarena, Departamento de Farmacobiología, Calzada de los Tenorios 235, Col Granjas Coapa, Deleg Tlalpan, CP 14330 México DF, México, Fax: +55 483 2863,

E-mail: estrada@imp.edu.mx

Received 7 May 2002; revised 8 October 2002; accepted 14 October 2002

online publication: 22 October 2002 at http://www.acnp.org/citations/ Npp I022024I3
}

catecholamine reuptake inhibitors (ie desipramine (DMI), maprotiline, bupropion) produce initially a blockade of their respective reuptake sites, thereby enhancing the neurotransmitter availability (Hervás and Artigas, 1998; Kreiss and Lucki, 1995; Linner et al, 1999; Piñeyro and Blier, 1999; Stahl, 1998a). Later, this increased availability promotes adaptive changes on specific receptor systems, as it has been shown for the $5-\mathrm{HT}_{1 \mathrm{~A}}, 5-\mathrm{HT}_{2 \mathrm{~A} / \mathrm{C}}$ and for the noradrenergic $\alpha_{2}$ and $\beta$ receptor subtypes (Blier, 2001; Blier and Montigny, 1994; Chaput et al, 1991; Dawson and Nguyen, 1998; Duman, 1999; Gobert and Millan, 1999; Le Poul et al, 2000; Stahl, 1998a). On the other hand, in vitro studies demonstrate that estrogens can interact, at several levels, with the dopaminergic, the noradrenergic, and the serotonergic systems (Attali et al, 1997; Bethea et al, 1998; Biegon et al, 1983; Cyr et al, 2000; McEwen, 1999; Rubinow et al, 1998). For example, estrogens can inhibit the function of the monoaminergic transporter (Ghraf et al, 1983; Michel et al, 1987; Wilson et al, 1988) and interact with either $5-\mathrm{HT}_{1 \mathrm{~A}}, 5-\mathrm{HT}_{2 \mathrm{~A}}$, or $\beta$-adrenergic receptors in several brain areas (Biegon et al, 1983; Fink et al, 1996; Kendall et al, 1982; Mize and Alper, 2000; Österlund et al, 1999; Raap et $a l$, 2000; Sumner and Fink, 1995). Interestingly, estrogenic compounds modify those neurotransmitter systems that are targets of antidepressant treatments.

It is important to mention that the estrogenic activity on each of these systems varies depending on the estrogen nature (Chang and Chang, 1999; Ghraf et al, 1983; Michel et $a l, 1987)$. Thus, the natural estrogen $\mathrm{E}_{2}$ decreases both serotonin and noradrenaline reuptake sites, being more 
potent at the serotonergic than at the noradrenergic system (Ghraf et al, 1983; Michel et al, 1987). By contrast, the synthetic steroidal compound, ethynil-estradiol $\left(\mathrm{EE}_{2}\right)$, inhibits, with comparable efficacy, both the serotonergic and the catecholaminergic transporters (Ghraf et al, 1983; Michel et al, 1987). Finally, the nonsteroidal synthetic estrogen diethyl-stilbestrol (DES) decreases dopaminergic and noradrenergic reuptake sites (Ghraf et al, 1983) without producing changes in the number or affinity of serotonergic transporters (Chang and Chang, 1999).

On these bases, the main purpose of the present study was to investigate the possible antidepressant-like effect of three types of estrogens: a natural estrogen $\left(\mathrm{E}_{2}\right)$; a synthetic steroidal estrogen $\left(\mathrm{EE}_{2}\right)$; and a synthetic nonsteroidal estrogen (DES) in the forced swimming test (FST).

The FST is an animal model commonly used for both the screening of antidepressant drugs (Borsini, 1995; Borsini and Meli, 1988; Porsolt and Lenégre, 1992) and the analysis of the neurobiological bases of depression (Duncan et al, 1985; Paul et al, 1990). In this model, rats are forced to swim and eventually adopt a floating posture identified as immobility behavior (Borsini and Meli, 1988; Porsolt et al, 1977; Porsolt and Lenégre, 1992), which is considered as an index of 'behavioral despair' (Porsolt et al, 1977, 1978; Porsolt and Lenégre, 1992). In the FST, antidepressants induce a decrease in immobility (Borsini and Meli, 1988; Kitada et al, 1983; Porsolt et al, 1977). Detke et al (1995) pointed out that in addition to immobility, it is also possible to register two active behaviors, swimming and climbing, which appear to be sensitive to specific antidepressant drug classes (Detke et al, 1995; Lucki, 1997). Thus, SSRIs such as FLX, paroxetine, or sertraline decrease immobility and increase swimming (Cryan and Lucki, 2000; Detke et al, 1995; Espejo and Minano, 1999; Page et al, 1999), while the selective noradrenergic and dopaminergic reuptake inhibitors, like DMI, maprotiline, and bupropion, decrease immobility accompanied by an increase in climbing behavior (Detke et al, 1995; Espejo and Minano, 1999; Hemby et al, 1997; Rénéric and Lucki, 1998). Hence a second purpose of this investigation was to determine the behavioral profiles induced by the estrogenic compounds and compare them with those produced by the classic antidepressants FLX and DMI in the FST.

Finally, several authors suggest that estrogens can induce early and long-lasting changes in the monoaminergic systems (McEwen, 1999; McEwen et al, 2001; Mize and Alper, 2000; Österlund and Hurd, 1998). For instance, a functional desensitization of $5-\mathrm{HT}_{1 \mathrm{~A}}$ receptors occurs minutes after $\mathrm{E}_{2}$ treatment (Mize and Alper, 2000) and endures at least $24 \mathrm{~h}$ (Raap et al, 2000). Therefore, a third purpose of this study was to analyze the temporal course of the antidepressant-like effect of an acute administration of the three different estrogenic compounds in the FST.

\section{MATERIALS AND METHODS}

\section{Animals}

Ovariectomized female Wistar rats (250-300 g) were housed in groups of six and maintained on a $12 \mathrm{~h}$ light-dark cycle (lights off at 10:00-22:00 h) in a temperature-controlled $\left(22^{\circ} \mathrm{C}\right)$ room. The rats had free access to food and water, and were handled for 3-5 days prior to behavioral testing. All experimental procedures were performed in accordance with the Mexican official norm for animal care and handling (NOM-062-ZOO-1999) and approved by our Institutional Ethics Committee.

\section{Surgical Procedures}

Ovariectomy was performed under ethylic ether anesthesia. Briefly, a single midline incision was made in the ventral area, oviducts were exposed, and ovaries removed. Complete ovariectomy was evaluated by visual inspection of the ovaries after their extraction. After 3 weeks, animals were randomly assigned to an experimental group and behavioral studies performed.

\section{FST}

Swimming sessions were conducted by placing rats into individual glass cylinders $(46 \mathrm{~cm}$ height $\times 20 \mathrm{~cm}$ diameter containing $23-25^{\circ} \mathrm{C}$ water $30 \mathrm{~cm}$ deep, so that rats could not support themselves by touching the bottom with their paws. Two swimming sessions were conducted: an initial 15-min pretest followed $24 \mathrm{~h}$ later by a 5 -min test. Following each swimming session, the rats were removed from the cylinders, dried with paper towels and placed in heated cages for $30 \mathrm{~min}$, and then returned to their home cages. Test sessions were run between 12:00 and 15:00 h and videotaped for later scoring. A single observer, who was blind to the treatment conditions, did all the behavioral scoring.

\section{Behavioral Scoring}

A time sampling technique was employed to score three different behaviors (Detke et al, 1995). During the test session, the scorer rated at the end of each 5-s period the following rat behaviors: (1) immobility-floating in the water without struggling, and doing only those necessary movements to keep the head above the water; (2) swimming - showing moderate active motions around in the cylinder, more than necessary to merely keep the head above water; and (3) climbing - presenting active vigorous movements with forepaws in and out of the water, usually directed against the walls.

\section{Open-Field Test}

In order to discard a possible influence of drug treatments on locomotor activity, the effect of the estrogenic compounds and antidepressant drugs in the open-field test was tested. The apparatus consisted of an opaque-Plexiglas box $\left(40 \times 30 \times 20 \mathrm{~cm}^{3}\right)$ with the floor divided into 12 equal squares $\left(11 \times 11 \mathrm{~cm}^{2}\right)$. The animals were placed in a corner of the apparatus and an observer, blind to the pharmacological treatments, registered the number of times the animal crosses squares during a 5-min session (MartínezMota et al, 1999; Estrada-Camarena et al, 2002).

\section{Drugs}

Estrogenic compounds: $\mathrm{E}_{2}, \mathrm{EE}_{2}$, and DES (Sigma-Aldrich, St Louis, MO, USA) were dissolved in corn oil and injected 
(subcutaneous) in $0.2 \mathrm{ml} /$ rat. Desipramine hydrochloride (Sigma-Aldrich, St Louis, MO, USA) and fluoxetine chlorhydrate (Eli-Lilly Company, México) were dissolved in saline solution and s.c. administered in $2.0 \mathrm{ml} / \mathrm{kg}$.

\section{Experimental Design}

All experiments were conducted with an independent group design ( $n=10-14$ per dose). In order to analyze the possible antidepressant-like effect of the estrogenic compounds, different doses of $\mathrm{E}_{2}(2.5-10.0 \mu \mathrm{g} / \mathrm{rat}), \mathrm{EE}_{2}(1.25-10 \mu \mathrm{g} / \mathrm{rat})$, or DES $(0.25-1.0 \mathrm{mg} / \mathrm{rat})$ were evaluated in the FST. In addition, the behavioral profile of these estrogenic compounds was compared with that produced by the antidepressants FLX (2.5-10 mg/kg) and DMI (2.5-10.0 mg/kg). Control groups for antidepressants received saline solution and those for estrogens, corn oil. Antidepressant treatments were applied following a subacute schedule, that is, three injections administered before the FST $(23.5,5$, and $1 \mathrm{~h})$. For estrogenic compounds, a single dose of each steroid was administered $48 \mathrm{~h}$ before the FST. Latencies for drug administration were selected from previous reports (Detke et al, 1997; López-Rubalcava and Lucki, 2000; MartínezMota et al, 2000). Statistical analyses for each compound were performed using a one-way ANOVA test followed by Dunnett's test.

In the second part of the study, estrogens that showed antidepressant-like effects in the FST were subjected to a temporal course analysis. For this experiment, independent groups of animals (each of 6-8 rats) were tested in the FST at $1,2,4,8,12,24,48,72$, or $96 \mathrm{~h}$ after $\mathrm{E}_{2}(10 \mu \mathrm{g} / \mathrm{rat}), \mathrm{EE}_{2}$ $(5.0 \mu \mathrm{g} / \mathrm{rat})$, or vehicle administration. Data were analyzed by means of a two-way ANOVA test considering treatment and time as factors, followed by Dunnett's test.

Finally, in order to detect possible unspecific effects of estrogens or antidepressant treatments, only the doses that were active in the FST were tested in independent groups $(n=6)$ in the open-field test. Statistical analyses were performed using a one-way ANOVA followed by Dunnett's test.

\section{RESULTS}

Figure 1 shows the effects of FLX (panel a) and DMI (panel b) in the FST. Both compounds significantly decreased immobility behavior $\left(\mathrm{F}_{3,39}=5.95, p<0.003\right.$ for FLX and $\mathrm{F}_{3,45}=2.84, p<0.04$ for DMI). In addition, FLX significantly increased swimming behavior $\left(\mathrm{F}_{3,39}=6.82, p<0.001\right)$ without changing climbing behavior $\left(\mathrm{F}_{3,39}=0.36\right.$, NS; Figure 1a). By contrast, DMI enhanced climbing $\left(\mathrm{F}_{3,45}=4.58\right.$, $p<0.007)$ without modifying swimming behavior $\left(\mathrm{F}_{3,45}=1.38\right.$, NS; Figure $\left.1 \mathrm{~b}\right)$.

In Figure $2 \mathrm{a}$, it can be observed that $\mathrm{E}_{2}$ significantly reduced immobility behavior $\left(\mathrm{F}_{3,42}=5.35, p<0.003\right)$ with a concomitant increase in swimming behavior $\left(\mathrm{F}_{3.42}=9.97\right.$, $p<0.001)$ and no change in climbing $\left(\mathrm{F}_{3,42}=1.72, \mathrm{NS}\right)$.

On the other hand, the synthetic estrogen $\mathrm{EE}_{2}$ at doses of 2.5 and $5 \mu \mathrm{g} / \mathrm{rat}$ (Figure $2 \mathrm{~b}$ ) significantly decreased
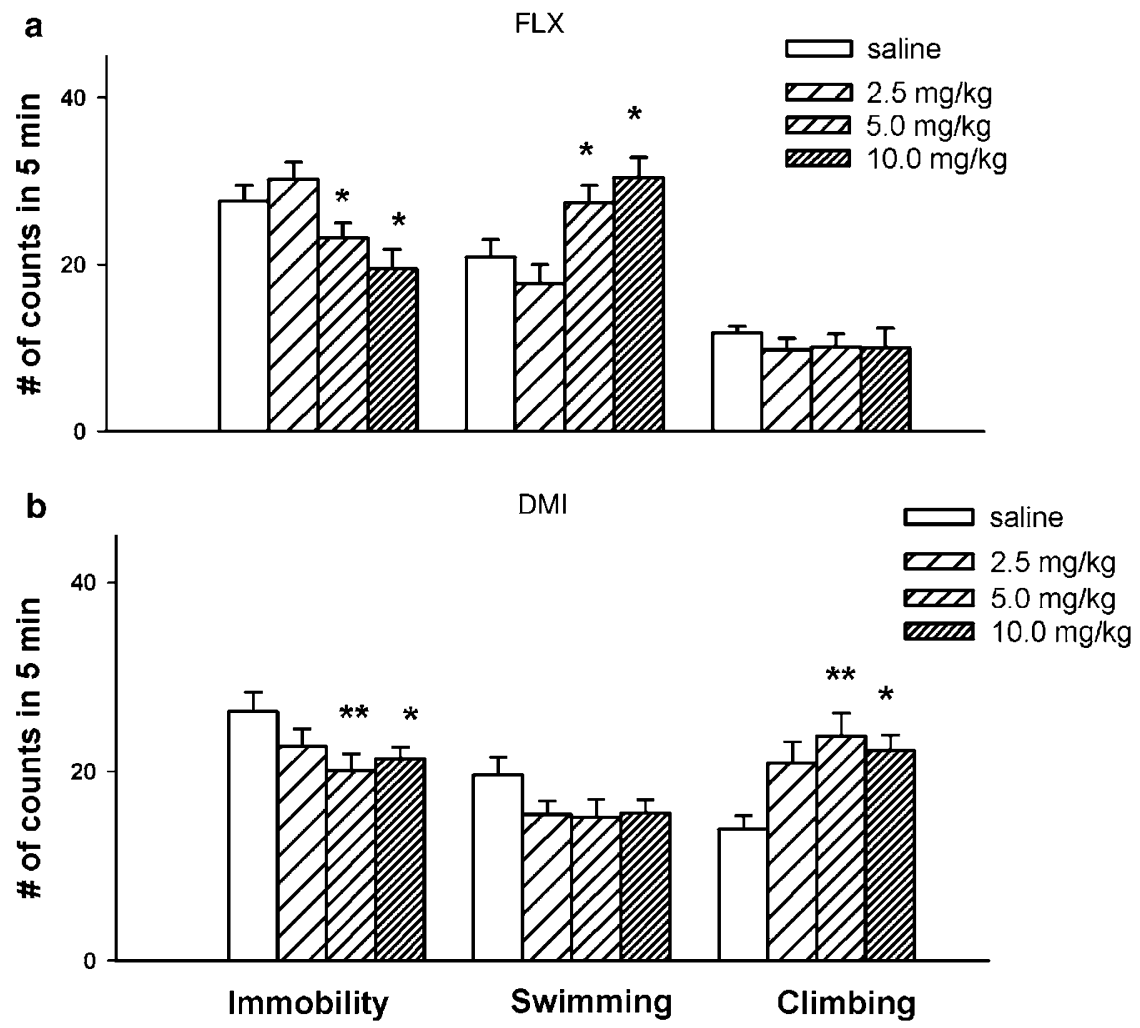

Figure I Behavioral effects produced by different doses of fluoxetine ( FLX, $-23.5,-5,-1 \mathrm{~h}$, panel a, $n=10-12$ rats per group) and desipramine (DMI, $-23.5,-5,-1 \mathrm{~h}$, panel $\mathrm{b}, n=12-13$ rats per group) in the FST. Values represent mean of counts (+ I SEM) of immobility, swimming, and climbing behaviors when sampled every $5 \mathrm{~s}$ during a 5 -min test period. For one-way ANOVAs, see text. Comparisons vs control group, Dunnett's test, * $p<0.05$, *** $<0.01$. 
a

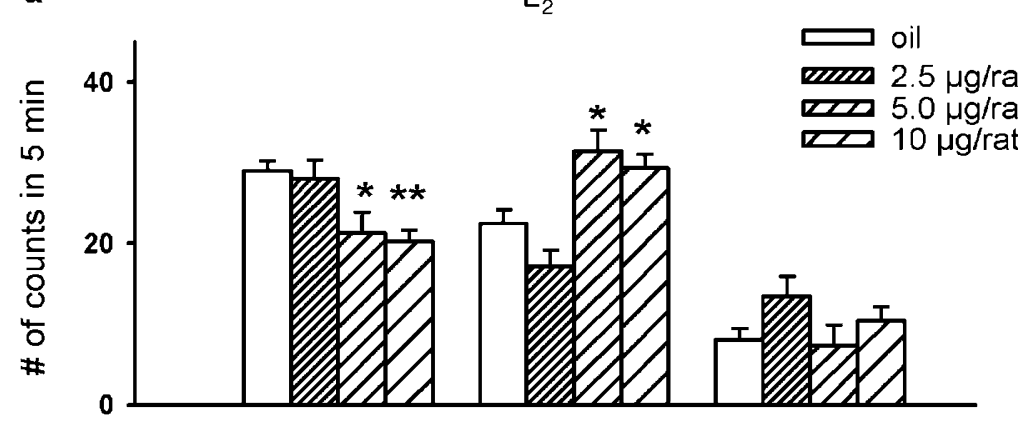

b

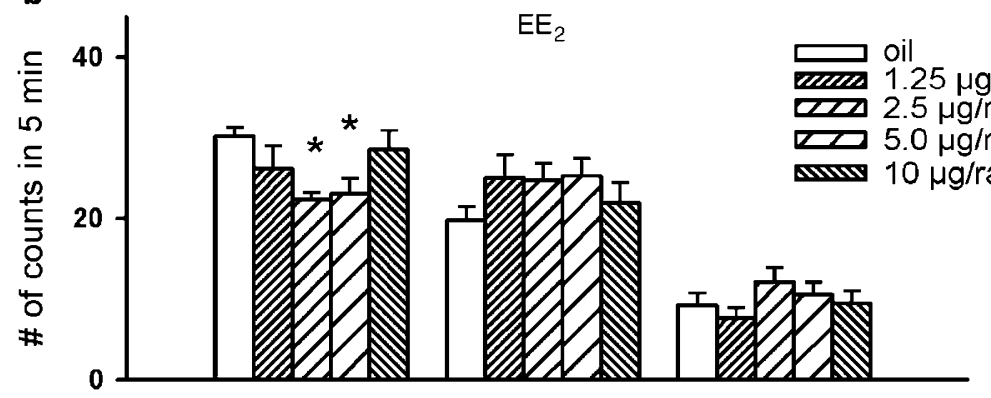

C

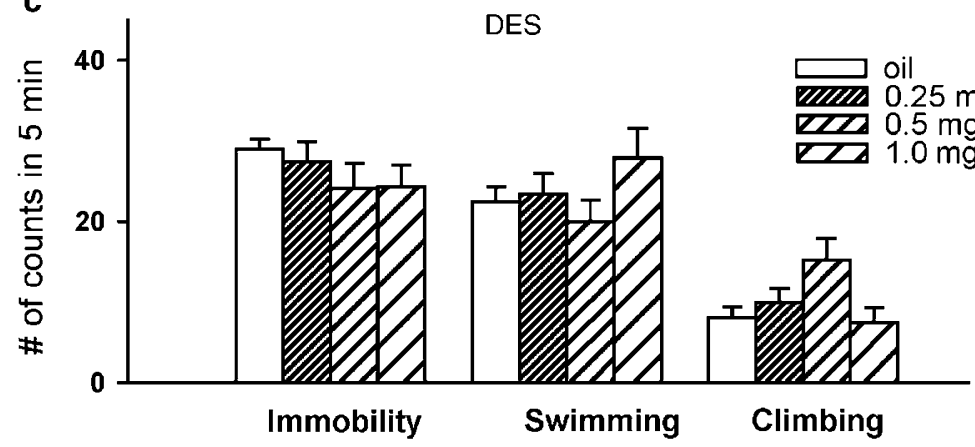

Figure 2 Behavioral effects produced by different doses of $17 \beta$-estradiol $\left(E_{2},-48 \mathrm{~h}\right.$, panel $a, n=10-12$ rats per group), ethynil-estradiol (EE 2 , $-48 \mathrm{~h}$, panel $b, n=12-14$ rats per group) and diethyl-stilbestrol (DES, $-48 \mathrm{~h}$, panel $c, n=10-12$ rats per group) in the FST. Values represent mean of counts ( +1 SEM) of immobility, swimming, and climbing behaviors when sampled every $5 \mathrm{~s}$ during a 5 -min test period. For one-way ANOVAs, see text. Comparisons vs control group, Dunnett's test, $*$ $p<0.05$, $* * 0<0.01$.

immobility behavior $\left(\mathrm{F}_{4,62}=2.73, p<0.03\right)$ and showed a tendency towards an increase in swimming $\left(\mathrm{F}_{4,62}=0.97\right.$, NS) without affecting climbing $\left(\mathrm{F}_{4,62}=1.09\right.$, NS). A higher dose $(10 \mu \mathrm{g} / \mathrm{rat})$ shows a lack of an action on the parameters of the FST.

Finally, in marked contrast with the other estrogenic compounds, DES had no effect in the FST (Figure 2c). Thus, the immobility was not reduced after any dose of this compound $\left(\mathrm{F}_{3,40}=0.99\right.$, NS). Similarly, the swimming behavior was unaffected $\left(\mathrm{F}_{3,40}=0.28\right.$; NS). However, there was a tendency to increase the climbing behavior after the $0.5 \mathrm{mg} / \mathrm{rat}$ dose that was absent at the highest $(1.0 \mathrm{mg} / \mathrm{rat})$ dose level $\left(\mathrm{F}_{3,40}=3.04, p<0.04\right)$.

The effect of the three different estrogenic compounds on locomotor activity is shown in Table 1 . None of the estrogens tested had an action on locomotor activity $\left(\mathrm{F}_{3,22}=0.319\right.$, NS). FLX $(10 \mathrm{mg} / \mathrm{kg})$ and DMI $(10 \mathrm{mg} / \mathrm{kg})$, on the other hand, significantly decreased locomotor activity $\left(\mathrm{F}_{2,15}=11.73, p<0.001\right)$.
Table I Effect of Estrogenic Compounds and Antidepressants in the Open-Field Test

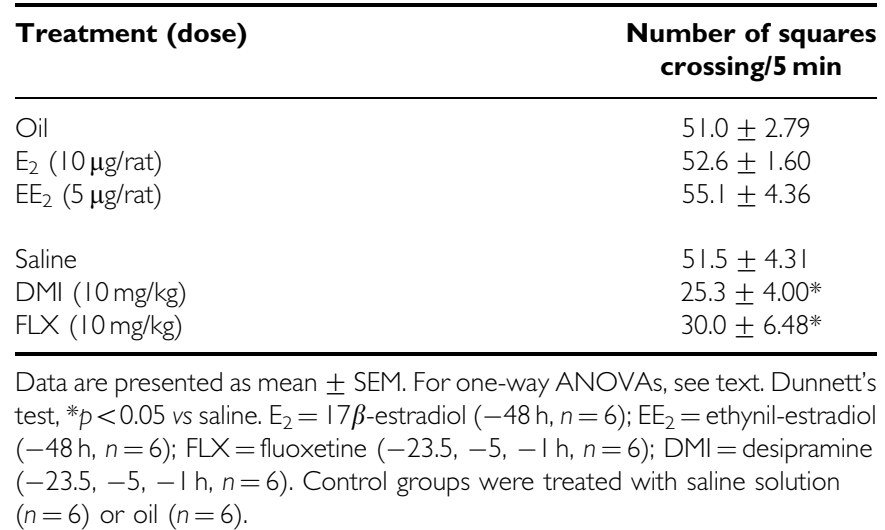



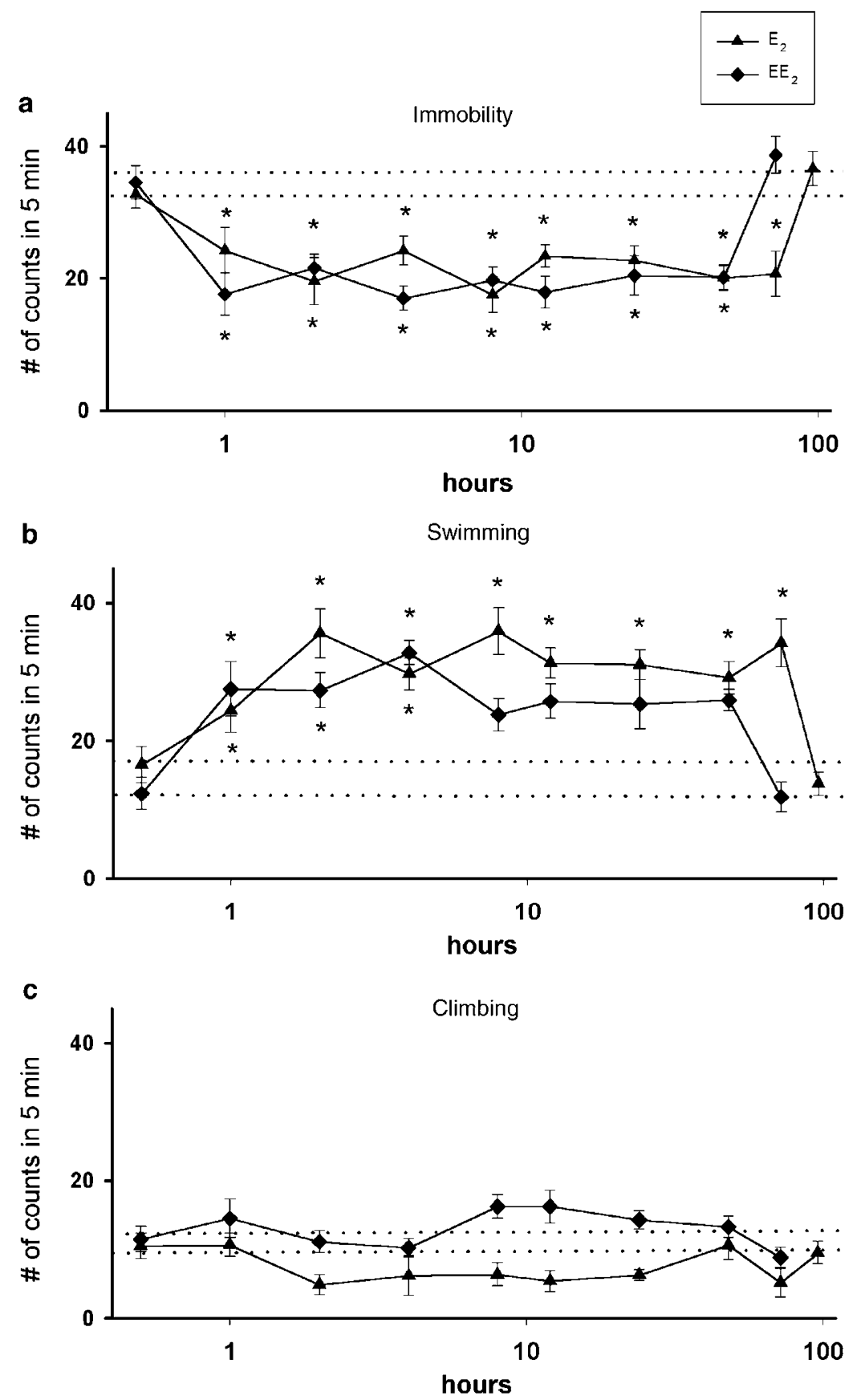

Figure 3 Time course effects for $17 \beta$-estradiol $\left(E_{2}, 10 \mu \mathrm{g} / \mathrm{rat}, n=7-8\right.$ rats per group) and ethynil-estradiol ( $E E_{2}, 5 \mu g /$ rat, $n=6-8$ rats per group) in the FST. Values represent mean \pm SEM of the number of counts of immobility (panel a), swimming (panel b), and climbing behaviors (panel c) when sampled every $5 \mathrm{~s}$ during a 5 -min test period. The dotted line represents the mean \pm SEM of control (oil injected, $n=6-7$ rats) group sessions. Time scale (in hours) is represented in log. For two-way ANOVAs, see text. Comparisons vs control group, Dunnett's test, $* 0<0.05$.

Since $\mathrm{E}_{2}$ and $\mathrm{EE}_{2}$ produced an antidepressant-like effect in the FST, the temporal course of these antidepressant-like actions was analyzed. $\mathrm{E}_{2}$ induced a reduction in immobility (Figure 3a) and an increase in swimming behavior (Figure 3b) $1 \mathrm{~h}$ after its administration. These effects lasted for $72 \mathrm{~h}$ (Figures $3 \mathrm{a}$ and $\mathrm{b}$ ). This compound did not modify the climbing behavior (Figure 3c).

$\mathrm{EE}_{2}$, on the other hand, induced a significant reduction in immobility $1 \mathrm{~h}$ after its injection and this effect remained for $48 \mathrm{~h}$ (Figure 3a). Interestingly, this estrogen produced an increase in swimming behavior that was statistically significant from control values during the first $4 \mathrm{~h}$ (Figure $3 \mathrm{~b})$. A slight increase in climbing behavior at 8 and $12 \mathrm{~h}$, which did not reach statistical significance, was observed (Figure 3c).

The two-way ANOVA test for the time course actions of $E_{2}$ and $\mathrm{EE}_{2}$ revealed significant differences in immobility behavior for treatment $\left(\mathrm{F}_{2,163}=48.07, p<0.001\right)$, time after injection $\left(\mathrm{F}_{8,163}=5.27, \quad p<0.001\right)$ and for the treatment $\times$ time interaction $\left(\mathrm{F}_{16,163}=3.16, p<0.001\right)$. In the 
case of swimming behavior, the two-way ANOVA test showed significant differences for treatment $\left(\mathrm{F}_{2,163}=68.81\right.$, $p<0.001)$, time $\left(\mathrm{F}_{8,163}=5.57, p<0.001\right)$ and for the treatment $\times$ time interaction $\left(\mathrm{F}_{16,163}=3.02, p<0.001\right)$. Finally, the two-way ANOVA test for the climbing behavior showed significant differences for treatment $\left(\mathrm{F}_{2,163}=23.01\right.$, $p<0.001)$ with no significant differences for the time after injection $\left(\mathrm{F}_{8,163}=1.17\right.$, NS $)$ or for the treatment $\times$ time interaction $\left(\mathrm{F}_{16,163}=1.67, \mathrm{NS}\right)$.

\section{DISCUSSION}

In the present study it was found that both the natural and the synthetic steroidal estrogens, $\mathrm{E}_{2}$ and $\mathrm{EE}_{2}$, respectively, had antidepressant-like actions in the FST while the nonsteroidal synthetic estrogen, DES, was inactive. The antidepressant-like effects lasted $48 \mathrm{~h}$ for $\mathrm{EE}_{2}$ and $72 \mathrm{~h}$ for $\mathrm{E}_{2}$.

The present study confirms the antidepressant-like effect reported for FLX and DMI. The reduction in immobility induced by FLX was accompanied by increased swimming, while that of DMI occurred with an increase in climbing behavior. The behavioral profiles observed in the present study with FLX or DMI, in ovariectomized female rats, are similar to those reported by other authors in male rats (Detke et al, 1995, 1997; Page et al, 1999; Rénéric and Lucki, 1998). Hence, the finding of Detke et al (1995) can also be extended to ovariectomized female rats.

Similar to the classical antidepressant treatments, $\mathrm{E}_{2}$ and $\mathrm{EE}_{2}$ reduced immobility behavior in the FST, an effect considered as an antidepressant-like action (Borsini, 1995; Borsini and Meli, 1988; Kitada et al, 1983; Porsolt et al, 1977, 1978). In line with the interpretations of Lucki and coworkers (Detke et al, 1995), the characteristic patterns of the active behaviors (swimming and climbing) in the FST would suggest that the serotonergic system participates in the antidepressant-like effect of $E_{2}$. This assumption arises from the fact that the behavioral profile induced by $\mathrm{E}_{2}$ was similar to that observed after FLX, characterized by a decreased immobility and an increased swimming without modifying climbing (Detke et al, 1995; Page et al, 1999). However in vitro evidence shows that $\mathrm{E}_{2}$ inhibits both the noradrenergic and the serotonergic reuptake sites (Ghraf et al, 1983; Michel et al, 1987). Interestingly, $\mathrm{E}_{2}$ activity at the serotonergic transporter is superior to that exerted at the noradrenergic reuptake site (Ghraf et al, 1983; Michel et al, 1987), a difference that could underlie the behavioral profile observed. In line with this idea, the administration of the antidepressant venlafaxine, another mixed 5-HT/NA reuptake inhibitor (but more effective in inhibiting 5-HT than NA reuptake) (Béïque, 1999), also decreased immobility accompanied by an increased swimming without modifying climbing (Rénéric and Lucki, 1998). As to in vivo studies, although there are several reports (at least seven) that analyze the actions of $\mathrm{E}_{2}$ on serotonergic reuptake sites, the results are inconclusive. Thus increases, decreases, and nochange on the serotonergic transporter are all reported (Attali et al, 1997; Cardinali and Gómez, 1977; Everitt et al, 1975; McQueen et al, 1997; Mendelson et al, 1993; Rehavi et al, 1987; Wilson et al, 1988). It is possible that the discrepancies could rely on variables such as the time elapsed between ovariectomy and estrogen treatment, the duration of estrogen treatment (acute $v s$ chronic), the type of ligands used, and the site of the brain evaluated. It is also important to mention that none of these studies had similar conditions to the ones used in the present study (3 weeks after ovariectomy, a single steroid administration $48 \mathrm{~h}$ before the test). Thus, future experiments in vivo should be undertaken to analyze specifically the actions of $E_{2}$ on serotonin and noradrenaline reuptake sites under these experimental conditions.

Similar to $E_{2}$ the synthetic estrogen $E_{2}$ decreased immobility behavior; however, in contrast to $\mathrm{E}_{2}$, it showed a tendency to increase swimming. Interestingly, in vitro studies have shown that $\mathrm{EE}_{2}$ inhibits both catecholaminergic and serotonergic reuptake sites with a similar potency (Ghraf et al, 1983; Michel et al, 1987). It is possible that this type of interaction could be reflected in the behavioral profile observed with this estrogen in the FST. The lack of significant increases of $\mathrm{EE}_{2}$ on swimming behavior could be masked by the action of this steroid on the catecholaminergic system. Other authors analyzing the effect of duloxetine (a mixed 5-HT/NA reuptake inhibitor), PPT (8-methyl-2 $\beta$-propanoyl-3 $\beta$-(4-(-1-methylphenyl)-8-azabyciclo[3,2,1] octane)), that is a DA, NA and 5-HT reuptake inhibitor, observed a similar behavioral profile (Hemby et al, 1997; Rénéric and Lucki, 1998).

Interestingly, $\mathrm{EE}_{2}$ showed a biphasic effect in the FST. Thus, low doses of this steroid ( 2.5 and $5 \mu \mathrm{g} / \mathrm{rat})$ induced an antidepressant-like action whereas the highest dose had no effect. Clinical reports have found similar results; for example, Prange (1972) reported that low doses of $\mathrm{EE}_{2}$ facilitate the action of the antidepressant imipramine whereas high doses had no effect. The reason for the biphasic action of $\mathrm{EE}_{2}$ is unknown; it is possible that high doses of this compound induce unspecific actions that interfere with its antidepressant effect. Future experiments should be performed to further analyze this point.

By contrast to the other estrogenic compounds, DES did not show antidepressant-like action in this animal model of depression. In vitro studies have reported that DES interacts to a lesser extent with the noradrenergic system than other estrogenic compounds, such as $\mathrm{E}_{2}$ and $\mathrm{EE}_{2}$ (Ghraf et al, 1983), and that it does not affect the serotonergic reuptake sites (Chang and Chang, 1999). These data might explain its lack of effect in the FST. However, specific experiments are necessary to confirm this hypothesis.

In general, the biological actions of estrogens can be mediated through a rapid nongenomic and a delayed genomic mechanism (Cyr et al, 2000; McEwen, 1991, 1999; Wehling, 1997; Wise et al, 2001). The first mechanism is mediated by membrane receptors and second messengers (Cyr et al, 2000; McEwen et al, 2001; Nadal et al, 2000). The other mechanism involves the interaction with intracellular receptors that implies the activation of transcription factors (McEwen, 1991; McEwen et al, 2001). It is possible that both mechanisms participate in the effects of estrogens in the FST. Regarding the involvement of the rapid nongenomic mechanism, present data found an antidepressant-like effect of both $\mathrm{E}_{2}$ and $\mathrm{EE}_{2}$ already $1 \mathrm{~h}$ after their injection. In vitro and in vivo studies showed that acute injection of $\mathrm{E}_{2}$ promotes a rapid (from $10 \mathrm{~min}$ to $2 \mathrm{~h}$ ) functional desensitization of $5-\mathrm{HT}_{1 \mathrm{~A}}$ and $5-\mathrm{HT}_{1 \mathrm{~B}}$ receptors (Mize and Alper, 2000; Österlund and Hurd, 1998, 2001) and an inhibition of 
serotonergic reuptake sites (Chang and Chang, 1999). Similar actions have been reported after chronic treatment with FLX and paroxetine ( $\mathrm{Li}$ et al, 1996, 1997a). Thus, it is possible that the early antidepressant-like effect of estrogens involves the inhibition of reuptake sites leading to a rapid desensitization of $5-\mathrm{HT}_{1 \mathrm{~A}}$ and $5-\mathrm{HT}_{1 \mathrm{~B}}$ receptors (Chang and Chang, 1999; Mize and Alper, 2000).

In relation to the long-lasting antidepressant-like effects observed several days after a single estrogen injection, at least two nonexclusive mechanisms can be proposed. Some authors have reported a genomic effect evidenced by an increase in mRNA levels associated with an augmented 5$\mathrm{HT}_{2 \mathrm{~A}}$ receptor density in the frontal cortex and nucleus accumbens expressed 24-30 h after $\mathrm{E}_{2}$ (Sumner et al, 1998; Sumner and Fink, 1995). Furthermore, such increase was blocked after the administration of the estrogen receptor antagonist tamoxifen (Sumner et al, 1998). These effects could be related to the long-lasting antidepressant-like actions of estrogens in the FST. It is notable that the $5-\mathrm{HT}_{2 \mathrm{~A}}$ receptor is also associated with antidepressant effects (Barnes and Sharp, 1999; Einat et al, 2001; Li et al, 1997b; Lucki et al, 1994; Massou et al, 1997; Raap and Van de Kar, 1999). The other proposed mechanism implies adaptive changes on the serotonergic and noradrenergic receptors that increase the cAMP response element binding protein (CREB) and the brain-derived neurotrophic factor (BDNF). Interestingly, the expression of CREB and BDNF is regulated by both estrogens (Murphy et al, 1998; Murphy and Segal, 1997) and antidepressants (Duman et al, 1997, 1999; Nibuya et al, 1996; Siuciak et al, 1997). Moreover, the intrahippocampal injection of BDNF induces an antidepressant-like effect in the FST that endures at least 10 days (Shirayama et al, 2002). Future studies should be undertaken to further examine these hypotheses.

Recently, we have found that the antidepressant-like actions of estrogens are antagonized by either WAY 100635, a specific $5-\mathrm{HT}_{1 \mathrm{~A}}$ blocker, or RU 58668, a selective estrogen antagonist (unpublished data). These results are in favor of the participation of both a nongenomic mechanism that primarily implies the interaction of estrogen with serotonergic receptors (see above) and a classic genomic one that considers the binding of estrogen to its intracellular receptors. Most likely, both mechanisms are involved in the antidepressant-like estrogen actions since DES, an active nonsteroidal compound that effectively interacts with the intracellular estrogen receptor (Chang and Chang, 1999; Jordan et al, 1985) but that almost lacks monoaminergic actions (see above), failed to induce changes in the FST.

The open-field test was designed to study the exploratory activity in rats and is commonly used in combination with the FST to discard unspecific actions of antidepressant treatments (Borsini et al, 1985; Borsini and Meli, 1988; Porsolt et al, 1978). In the present study we observed that none of the estrogen treatments produced changes in locomotor activity, indicating that the antidepressant-like activity showed by $\mathrm{E}_{2}$ and $\mathrm{EE}_{2}$ is not due to nonspecific changes in locomotion. By contrast, DMI and FLX reduced locomotor activity but increased active behaviors in the FST. Thus: the diminution in locomotor activity did not interfere with the expression of active behaviors indicating that the anti-immobility effect of FLX and DMI is specific in the FST.
In conclusion, $\mathrm{E}_{2}$ and $\mathrm{EE}_{2}$ possess long-lasting antidepressant-like effects in the FST. The different behavioral profile of these estrogens could be related with their ability to interact with the noradrenergic and serotonergic systems.

\section{ACKNOWLEDGEMENTS}

We thank Dr Rodríguez-Manzo for her comments on the manuscript and Eli-Lilly Company (México) for their kind donation of FLX. EE-C received a doctoral fellowship from CONACYT (96 338).

\section{REFERENCES}

Ahonkas A, Kaukoranta J, Aito M (1999). Effect of estradiol on postpartum depression. Psychopharmacology 146: 108-110.

Attali G, Weizman A, Gil-Ad I, Rehavi M (1997). Opposite modulatory effects of ovarian hormones on rat brain dopamine and serotonin transporters. Brain Res 756: 153-159.

Barnes N, Sharp T (1999). A review of central 5-HT receptors and their function. Neuropharmacology 38: 1083-1152.

Béique J-C, Montigny C, Blier P, Debonnald C (1999). Venlafaxine: discrepancy between in vivo 5-HT and NE reuptake blockade and affinity for reuptake sites. Synapse 32: 198-211.

Bernardi M, Vergoni A, Sandrini M, Tagliavini S, Bertolini A (1989). Influence of ovariectomy, estradiol and progesterone on the behavior of mice in an experimental model of depression. Physiol Behav 45: 1067-1068.

Bethea CL, Pecins-Thompson M, Schutzer W, Gundlah C, Lu Z (1998). Ovarian steroids and serotonin neural function. Mol Neurobiol 18: 87-122.

Biegon A, Reches A, Snyder L, McEwen B (1983). Serotonergic and noradrenergic receptors in the rat brain: modulation by chronic exposure to ovarian hormones. Life Sci 32: 2015-2021.

Blier P (2001). Possible neurobiological mechanisms underlying faster onset of antidepressant action. J Clin Psychiat 62: 7-11.

Blier P, Montigny C (1994). Current advances and trends in the treatment of depression. TIPS 15: 220-226.

Borsini F (1995). Role of serotonergic system in the forced swimming test. Neurosci Biobehav Rev 19: 377-395.

Borsini F, Meli A (1988). Is the forced swimming test a suitable model for revealing antidepressant activity? Psychopharmacology (Berl) 94: 147-160.

Borsini F, Pulvirenti L, Samanin R (1985). Evidence of dopamine involvement in the effect of repeated treatment with various antidepressants in the behavioral 'despair' test in rats. Eur J Pharmacol 110: 253-256.

Cardinali D, Gómez E (1977). Changes in hypothalamic noradrenaline, dopamine and serotonin uptake after oestradiol administration to rats. $J$ Endocrinol 73: 181-182.

Chang A, Chang S (1999). Nongenomic steroidal modulation of high-affinity serotonin transport. Biochem Biophys Acta 1417: 157-166.

Chaput Y, Montigny C, Blier P (1991). Presynaptic and postsynaptic modifications of the serotonin system by long-term administration of antidepressant treatments. An in vivo electrophysiologic study in the rat. Neuropsychopharmacology 5: 219229.

Cryan J, Lucki I (2000). Antidepressant-like behavioral effects mediated by 5-hydroxytryptamine ${ }_{2 \mathrm{C}}$ receptors. J Pharmacol Exp Ther 295: 1120-1126.

Cyr M, Calon F, Morissette M, Grandbois M, Di Paolo T, Callier S (2000). Drugs with estrogen-like potency and brain activity: potential therapeutic application for the CNS. Curr Pharm Des 6: $1287-1312$. 
Dawson L, Nguyen H (1998). Effects of 5- $\mathrm{HT}_{1 \mathrm{~A}}$ receptor antagonist on fluoxetine-induced changes in extracellular serotonin concentrations in rat frontal cortex. Eur J Pharmacol 345: 41-46.

Detke M, Johnson J, Lucki I (1997). Acute and chronic antidepressant drug treatment in the rat forced swimming test model of depression. Exp Clin Psychopharmacol 5: 107-112.

Detke M, Rickels M, Lucki I (1995). Active behaviors in the rat forced swimming test differentially activated by serotonergic and noradrenergic antidepressants. Psychopharmacology 121: 66-72.

Duman R (1999). The neurochemistry of mood disorders: preclinical studies. In: Charney D, Nestler E, Bunney B (eds). Neurobiology of Mental Illness, 1st edn. Oxford University Press pp 333-347.

Duman R, Heninger G, Nestler E (1997). A molecular and cellular theory of depression. Arch Gen Psychiatry 54: 597-606.

Duncan G, Paul I, Harden K, Mueller R, Stumpf W, Breese G (1985). Rapid down-regulation of beta-adrenergic receptors by combining antidepressant drugs with forced swim: a model of antidepressant-induced neural adaptation.J Pharmacol Exp Ther 234: 402-408.

Einat H, Clenet F, Shaldubina A, Belmaker R, Bourin M (2001). The antidepressant activity of inositol in the forced swimming test involves 5- $\mathrm{HT}_{2}$ receptors. Behav Brain Res 118: 77-83.

Epperson C, Wisner K, Yamamoto B (1999). Gonadal steroids in the treatment of mood disorders. Psychosom Med 61: 676-697.

Espejo E, Minano F (1999). Prefrontocortical dopamine depletion induces antidepressant-like effects in rats and alters the profile of desipramine during Porsolt's test. Neuroscience 88: 609-615.

Estrada-Camarena E, Contreras CM, Saavedra M, Luna-Baltazar I, López-Rubalcava C (2002). Participation of the lateral septal nuclei (LSN) in the antidepressant-like actions of progesterone in the forced swimming test (FST). Behav Brain Res 134: 175183.

Everitt B, Fuxe K, Hokfelt T, Jonsson G (1975). Role of monoamines in the control by hormones of sexual receptivity in the female rat. J Comp Physiol Psychol 89: 556-572.

Fink G, Sumner B, Rosie R, Grace O, Quinn J (1996). Estrogen control of central neurotransmission: effect on mood, mental state, and memory. Cell Mol Neurobiol 16: 325-344.

Galea L, Wide J, Barr A (2001). Estradiol alleviates depressive-like symptoms in a novel animal model of post-partum depression. Behav Brain Res 122: 1-9.

Genazzani A, Spinetti A, Gallo R, Bernardi F (1999). Menopause and the central nervous system: intervention options. Maturitas 31: 103-110.

Ghraf R, Michel M, Hiemke C, Knuppen R (1983). Competition by monophenolic estrogens and catecholestrogens for high-affinity uptake of $[3 \mathrm{H}](-)$-norepinephrine into synaptosomes from rat cerebral cortex and hypothalamus. Brain Res 277: 163-168.

Gobert A, Millan M (1999). Modulation of dialysate levels of dopamine, noradrenaline, and serotonin $(5-\mathrm{HT})$ in the frontal cortex of freely moving rats by (-)-pindolol alone and in association with 5-HT reuptake inhibitors: comparative roles of $\beta$-adrenergic, $5-\mathrm{HT}_{1 \mathrm{~A}}$ and $5-\mathrm{HT}_{1 \mathrm{~B}}$. Neuropsychopharmacology 21: 268-284.

Halbreich U, Endicott S, Goldstein S, Nee J (1986). Premenstrual changes and changes in gonadal hormones. Acta Psychiatr Scand 74: 576-586.

Hamilton J, Parry B, Blumenthal S (1988). The menstrual cycle in context, I: affective syndromes associated with reproductive hormonal changes. J Clin Psychiat 49: 474-480.

Hemby S, Lucki I, Gatto G, Singh A, Thornley C, Matasi J et al (1997). Potential antidepressant effect of novel tropane compounds, selective for serotonin or dopamine transporters. $J$ Phamacol Exp Ther 282: 727-733.

Hendrick V, Altshuler L, Suri R (1998). Hormonal changes in the post-partum and implications for post-partum depression. Psychosomatics 39: 93-101.
Hervás I, Artigas F (1998). Effect of fluoxetine on extracellular 5hydroxytryptamine in rat brain. Role of 5-HT autoreceptor. Eur J Pharmacol 358: 9-18.

Jordan C, Mittal S, Gosden B, Koch R, Lieberman M (1985). Structure-activity relationships of estrogens. Environ Health Perspect 61: 97-110.

Kendall D, Stancel G, Enna S (1982). The influence of sex hormones on antidepressant-induced alterations in neurotransmitter receptor binding. J Neurosci 2: 354-360.

Kitada Y, Miyauchi T, Kanazawa Y, Nakamichi H, Satoh S (1983). Involvement of $\alpha$ and $\beta$ 1-adrenergic mechanisms in the immobility reducing action of desipramine in the forced swimming test. Neuropharmacology 22: 1055-1060.

Klaiber E, Broverman D, Vogel W, Kobayashi T (1979). Estrogen therapy for severe persistent depressions in women. Arch Gen Psychiat 36: 550-554.

Kreiss DS, Lucki I (1995). Effects of acute and repeated administration of antidepressant drugs on extracellular levels of 5-hydroxytryptamine measured in vivo. J Pharmacol Exp Ther 274: 866-876.

Le Poul E, Boni C, Hanoun N, Laporte A-M, Laaris N, Chauveau J et al (2000). Differential adaptation of brain $5-\mathrm{HT}_{1 \mathrm{~A}}$ and $5-\mathrm{HT}_{1 \mathrm{~B}}$ receptors and 5-HT transporter in rats treated chronically with fluoxetine. Neuropharmacology 39: 110-122.

Li Q, Muma A, Battaglia G, Van de Kar L (1997a). A desensitization of hypothalamic $5-\mathrm{HT}_{1 \mathrm{~A}}$ receptors by repeated injections of paroxetine: reduction in the levels of $G_{i}$ and $G_{0}$ proteins and neuroendocrine responses, but not in density of $5-\mathrm{HT}_{1 \mathrm{~A}}$ receptors. J Pharmacol Exp Ther 282: 1581-1590.

Li Q, Muma N, Battaglia G, Van de Kar L (1997b). Fluoxetine gradually increases [ ${ }^{125} \mathrm{I}$ ] DOI-labelled $5-\mathrm{HT}_{2 \mathrm{~A} / 2 \mathrm{C}}$ receptors in the hypothalamus without changing the levels of $\mathrm{G}_{\mathrm{q}^{-}}$and $\mathrm{G}_{11^{-}}$proteins. Brain Res 775: 225-228.

Li Q, Muma A, Van de Kar L (1996). Chronic fluoxetine induces a gradual desensitization of $5-\mathrm{HT} 1_{\mathrm{A}}$ receptors: reductions in hypothalamic and midbrain $\mathrm{G}_{\mathrm{i}}$ and $\mathrm{G}_{0}$ proteins and in neuroendocrine responses to 5- $\mathrm{HT}_{1 \mathrm{~A}}$ agonist. J Pharmacol Exp Ther 279: 1035-1042.

Linnér L, Arborelius L, Nomikos G, Bertilsson L, Svensson T (1999). Locus coeruleus neuronal activity and noradrenaline availability in the frontal cortex of rats chronically treated with imipramine: effect of $\alpha_{2}$-adrenoceptor blockade. Biol Psychiat 46: 766-774.

López-Jaramillo P, Terán E, Molina G, Rivera J, Lozano A (1996). Oestrogens and depression. Lancet 348: 135-136.

López-Rubalcava C, Lucki I (2000). Strain differences in the behavioral effects of antidepressant drugs in the rat forced swimming test. Neuropsychopharmacology 22: 191-199.

Lucki I (1997). The forced swimming test as a model for core and component behavioral effects of antidepressant drugs. Behav Pharmacol 8: 523-532.

Lucki I, Singh A, Kreiss D (1994). Behavioral studies of serotonin receptor agonist as antidepressant drugs. Neurosci Biobehav Rev 18: 85-95.

Martínez-Mota L, Estrada-Camarena E, López-Rubalcava C, Contreras CM, Feránandez-Guasti A (2000). Interaction of desipramine with steroid hormones on experimental anxiety. Psychoneuroendocrinology 25: 109-120.

Martínez-Mota L, Contreras CM, Saavedra M (1999). Progesterone reduces immobility in rats forced to swim. Arch Med Res 30: 286-289.

Massou JM, Trichard C, Attar-Levy D, Feline A, Corruble E, Beaufils B et al (1997). Frontal $5-\mathrm{HT}_{2}$ receptors studied in depressive patients during chronic treatment by selective serotonin reuptake inhibitors. Psychopharmacology (Berl) 133: 99-101.

McEwen B (1991). Non-genomic and genomic effects of steroids on neural activiy. TIPS 12: 141-147. 
McEwen B (1999). The molecular and neuroanatomical basis of estrogen effects in the central nervous system. J Clin Endocrinol Metab 84: 1790-1797.

McEwen B, Akama K, Alves S, Brake W, Bulloch K, Lee S et al (2001). Tracking the estrogen receptor in neurons: implications for estrogen-induced synapse formation. Proc Natl Acad Sci USA 98: 7093-7100.

McQueen J, Wilson H, Fink G (1997). Estradiol-17 $\beta$ increases serotonin transporter (SERT) mRNA levels and the density of SERT-binding sites in female rat brain. Mol Brain Res 13-23.

Mendelson S, McKittrick C, McEwen B (1993). Autoradiographic analyses of the effect of estradiol benzoate on $\left[{ }^{3} \mathrm{H}\right]$ paroxetine binding in the cerebral cortex and dorsal hippocampus of gonadectomized male and female rats. Brain Res 601: 299-302.

Michel M, Rother A, Hiemke C, Ghraf R (1987). Inhibition of synaptosomal high-affinity uptake of dopamine and serotonin by estrogen agonists and antagonists. Biochem Pharmacol 36: 3175-3180.

Mize A, Alper R (2000). Acute and long-term effects of $17 \beta$ estradiol on $\mathrm{G}_{\mathrm{i} / \mathrm{o}}$ coupled neurotransmitter receptor function in the female rat brain as assessed by agonist-stimulated $\left[{ }^{35} \mathrm{~S}\right] \mathrm{GTP} \gamma$ S binding. Brain Res 859: 326-333.

Murphy D, Cole N, Segal M (1998). Brain derived neurotrophic factor mediates estradiol-induced dendritic spine formation in hippocampal neurons. Proc Natl Acad Sci USA 95: 11412-11417.

Murphy D, Segal M (1997). Morphological plasticity of dendritic spines in central neurons is mediated by activation of cAMP response element binding protein. Proc Natl Acad Sci USA 94: $1482-1487$

Nadal A, Ropero A, Laribi O, Maillet M, Fuentes E, Sorai B (2000). Nongenomic actions of estrogens and xenoestrogens by binding at a plasma membrane receptor unrelated to estrogen receptor $\alpha$ and estrogen receptor $\beta$. Proc Natl Acad Sci USA 97: 1160311608.

Nibuya M, Nestler E, Duman R (1996). Chronic antidepressant administration increases the expression of cAMP response element binding protein (CREB) in rat hippocampus. J Neurosci 16: 2365-2372.

Okada M, Hayashi N, Kometani M, Nakao K, Inukai T (1997). Influences of ovariectomy and continuous replacement of $17 \beta$ estradiol on the tail skin temperature and behavior in the forced swimming test in rats. Jpn J Pharmacol 73: 93-96.

Oppenheim G (1983). Estrogen in the treatment of depression: neuropharmacological mechanisms. Biol Psychiat 18: 721-725.

Österlund M, Hurd Y (1998). Acute $17 \beta$-estradiol treatment downregulates serotonin $5-\mathrm{HT}_{1 \mathrm{~A}}$ receptor mRNA expression in the limbic system of female rats. Mol Brain Res 55: 169-172.

Österlund M, Hurd Y (2001). Estrogen receptors in the human forebrain and the relation to neuropsychiatry disorders. Prog Neurobiol 64: 251-267.

Österlund M, Overstreet D, Hurd Y (1999). The flinders sensitive line rats, a genetic model of depression, show abnormal serotonin receptor mRNA expression in the brain that is reversed by $17 \beta$-estradiol. Mol Brain Res 74: 158-166.

Page M, Detke M, Dalvi A, Kirby L, Lucki I (1999). Serotonergic mediation of the effects of fluoxetine, but not desipramine, in the rat forced swimming test. Psychopharmacology 147: 162-167.

Paul I, Duncan G, Kuhn C, Mueller R, Hong S, Breese G (1990). Neural adaptation in imipramine-treated rats processed in forced swim test: assessment of time course, handling, rat, strain and amine uptake. J Pharmacol Exp Ther 252: 997-1005.

Piñeyro G, Blier P (1999). Autoregulation of serotonin neurons: role in antidepressant drug action. Pharmacol Rev 51: 533-591.

Porsolt R, Anton G, Blavet N, Deniel M, Jalfre M (1978). Behavioral despair in rats: a new model sensitive to antidepressant treatment. Eur J Pharmacol 47: 379-391.
Porsolt R, Lenégre A (1992). Behavioral models of depression. In: Elliot J, Heal D, Maisden C (eds). Experimental Approaches to Anxiety and Depression, 1st edn. Wiley: New York. pp 73-85.

Porsolt R, Le Pichon M, Jalfre M (1977). Depression: a new animal model sensitive to antidepressant treatments. Nature 266: 730 732.

Prange A (1972). Estrogen may well affect response to antidepressant. J Am Med Assoc 219: 143-144.

Raap D, DonCarlos L, García F, Muma N, Wolf W, Battaglia A, Van de Kar L (2000). Estrogen desensitizes 5- $\mathrm{HT}_{1 \mathrm{~A}}$ receptors and reduces levels of $\mathrm{G}_{\mathrm{z}}, \mathrm{G}_{\mathrm{i} 1}$ and $\mathrm{G}_{\mathrm{i} 3}$ proteins in the hypothalamus. Neuropharmacology 39: 1823-1832.

Raap D, Van de Kar L (1999). Selective serotonin reuptake inhibitors and neuroendocrine function. Life Sci 65: 1217-1235.

Rachman I, Unnerstall J, Pfaff D, Cohen R (1998). Estrogen alters behavior and forebrain c-fos expression in ovariectomized rats subjected to the forced swim test. Proc Natl Acad Sci USA 95: 13941-13946.

Rehavi M, Sepcuti H, Weizman A (1987). Upregulation of imipramine binding and serotonin uptake by estradiol in female rat brain. Brain Res 410: 135-139.

Rénéric J-P, Lucki I (1998). Antidepressant behavioral effects by dual inhibition of monoamine reuptake in the rat forced swimming test. Psychopharmacology (Berl) 136: 190-197.

Rubinow D, Schmidt P, Roca C (1998). Estrogen-serotonin interactions: implications for affective regulation. Biol Psychiat 44: 839-850.

Schneider L, Small G, Clary CM (2001). Estrogen replacement therapy and antidepressant response to sertraline in older depressed women. Am J Geriatr Psychiat 9: 393-399.

Schneider L, Small G, Hamilton S, Bystrisky A, Nemeroff C, Meyers B (1997). Estrogen replacement and response to fluoxetine in surgically menopauseal women. Am J Geriatr Psychiat 5: 97-106.

Shirayama Y, Chen A, Nakagawa S, Russell D, Duman R (2002). Brain derived neurotrophic factor produces antidepressant effects in behavioral models of depression. J Neurosci 22: 3251-3261.

Siuciak J, Lewis D, Wiegand S, Lindsay R (1997). Antidepressantlike effect of brain-derived neurotrophic factor (BDNF). Pharmacol Biochem Behav 56: 131-137.

Stahl S (1997). Sex therapy in psychiatry treatment has a new partner: reproductive hormones. J Clin Psychiat 58: 468-469.

Stahl S (1998a). Basic psychopharmacology of antidepressants. Part 1: antidepressants have seven distinct mechanisms of action. J Clin Psychiat 59: 5-14.

Stahl S (1998b). Basic psychopharmacology of antidepressants. Part 2: estrogen as an adjunct to antidepressant treatment. J Clin Psychiat 59: 15-24.

Sumner B, Grant K, Rosie R, Hegele-Hartung Ch, Fritzemeier K-H, Fink G (1998). Effects of tamoxifen on serotonin transporter and 5-hydroxytryptamine ${ }_{2 \mathrm{~A}}$ receptor binding sites and mRNA levels in the brain of ovariectomized rats with or without acute estradiol replacement. Mol Brain Res 73: 119-128.

Sumner B, Fink G (1995). Estrogen increases the density of 5hydroxytryptamine $\mathrm{A}_{\mathrm{A}}$ receptors in cerebral cortex and nucleus accumbens in female rat. J Steroid Biochem 54: 15-20.

Wehling M (1997). Specific, nongenomic actions of steroid hormones. Annu Rev Physiol 59: 365-393.

Wilson M, Dwyer K, Roy E (1988). Direct effects of ovarian hormones on antidepressant binding sites. Brain Res 22: 181185.

Wise P, Dubal D, Wilson M, Rau S, Böttner M (2001). Neuroprotective effects of estrogen - new insights into mechanisms of action. Endocrinology 142: 969-973. 